\title{
Biochemical responses of Hyacinth bean (Lablab purpureus) to salinity stress
}

\author{
Myrene R. D'Souza • Varadahally Rangaiah Devaraj
}

Received: 15 December 2008/Revised: 15 October 2009/Accepted: 4 November 2009/Published online: 25 November 2009

(C) Franciszek Górski Institute of Plant Physiology, Polish Academy of Sciences, Kraków 2009

\begin{abstract}
Effect of salinity on Hyacinth bean, Lablab purpureus (HA-4 cultivar) was evaluated in 10-day old seedlings with $100-500 \mathrm{mM} \mathrm{NaCl}$ over $72 \mathrm{~h}$ of exposure. The stress reduced dry and fresh weight, leaf surface area, root and shoot length, total chlorophyll, and RWC. Oxidative stress markers, $\mathrm{H}_{2} \mathrm{O}_{2}$, glutathione, TBARS, proline, ascorbic acid, total phenols, and total soluble sugar contents were significantly elevated. Salinity enhanced antioxidant enzymes, POX, and GR activities and reduced that of CAT in concentration and time dependent manner in leaves. Antioxidant enzymes in roots showed inverse relationship with concentration and time of exposure. Metabolic enzyme $\beta$-amylase activity increased in both leaves and roots. Acid phosphatase decreased in leaves and elevated in roots. Intensity of constitutive isozymes correlated with in vitro levels under stress, but the protein band patterns differed from controls. Lablab showed reasonable tolerance up to $300 \mathrm{mM} \mathrm{NaCl}$, but leaves and roots differed in their response.
\end{abstract}

Keywords Antioxidants - Antioxidant enzymes ·

Lablab purpureus $\cdot$ Proline $\cdot$ Salt stress $\cdot$ TBARS

$\begin{array}{ll}\text { Abbreviations } \\ \text { ASC } & \text { Ascorbate } \\ \text { APX } & \text { Ascorbate peroxidase } \\ \text { CAT } & \text { Catalase } \\ \text { EDTA } & \text { Ethylenediaminetetraacetic acid }\end{array}$

Communicated by M. Rapacz.

M. R. D’Souza · V. R. Devaraj ( $₫)$

Department of Biochemistry, Central College Campus,

Bangalore University, Bangalore 560001, India

e-mail: devaraj@bub.ernet.in

$\begin{array}{ll}\text { GR } & \text { Glutathione reductase } \\ \text { GSH } & \text { Reduced glutathione } \\ \text { MDA } & \text { Malondialdehyde } \\ \text { POX } & \text { Peroxidase } \\ \text { PPO } & \text { Polyphenoloxidase } \\ \text { PVP } & \text { Polyvinylpyrrolidone } \\ \text { ROS } & \text { Reactive oxygen species } \\ \text { RWC } & \text { Relative water content } \\ \text { SOD } & \text { Superoxide dismutase } \\ \text { TBARS } & \text { Thiobarbituric acid reactive substances } \\ \text { TCA } & \text { Trichloroacetic acid }\end{array}$

\section{Introduction}

Salinity is one of the major abiotic factors that limit the plant productivity. According to the FAO (2005), the total global area of salt-affected soils, including saline and sodic soils was 831 million ha (6\% of world's total land area). Apart from natural sodicity, 1,500 million ha of land farmed by dry-land agriculture, 32 million ha (2\%) are affected by secondary salinity to varying degrees. Most crop plants are susceptible to salinity even below $30 \mathrm{mM}$ (Chinnusamy et al. 2005). Salinity affects the plant growth by causing cytotoxicity and osmotic stress (Munns 2002). At higher salinity, the predominant cause of crop susceptibility may be due to ionic cytotoxicity via replacement of $\mathrm{K}^{+}$with $\mathrm{Na}^{+}$and non-covalent interaction of $\mathrm{Na}^{+}$and $\mathrm{Cl}^{-}$ with amino acids of proteins. The metabolic imbalances due to ionic toxicity, osmotic stress, and nutritional deficiency may lead to oxidative stress. Salt stress affects all major processes including photosynthesis, protein synthesis, lipid and energy metabolism (Parida and Das 2005). The ROS production, enhanced under saline conditions 
causes damage to cellular components, including membrane lipids (Mittova et al. 2004). Reaction of ROS with unsaturated fatty acids in membranes causes peroxidation leading to rapid desiccation and cell death. Damages to organelle membrane can result in loss of respiratory capacity in mitochondria and carbon fixing ability in chloroplasts (Zhu and Scandalios 1993).

Plants have evolved mechanisms to protect cellular and subcellular systems against the effect of ROS by employing enzymatic and non-enzymatic components. Enzymes such as POX, CAT, SOD, and GR form the antioxidant enzymatic component, while the non-enzymatic components include ascorbic acid, GSH, sugars, phenols etc. Apart from antioxidants and enzymes, ion transporters and osmolytes are also employed to resist salt stress. The degree of resistance of plants to salinity is often related to quantitative and qualitative changes in antioxidant systems. The role of non-enzymatic antioxidants such as carotenoids, ascorbate (ASC), glutathione (GSH), tocopherols, and proline is evident from a number of plants systems (Manchanda and Garg 2008). Similarly, increased SOD, APX, POX, CAT, and GR (Agarwal and Shaheen 2007) have been correlated to salinity tolerance. A number of salt-tolerant transgenic plants expressing antioxidant enzymes have been reported (Kolodyazhnaya et al. 2009).

Lablab purpureus (Hyacinth bean) is an important pulse crop in South East Asia and Eastern Africa. It is an excellent nitrogen fixer, and is grown as a cover crop or for livestock fodder. It is also used as an intercrop in India and Australia as a weed suppressor and soil erosion retardant (Maass et al. 2005). The plant is tolerant to mild salinity and is relatively drought tolerant. Except for the general information about its mild tolerance to salt and drought, there are no reports indicating biochemical and physiological bases of its response to salinity and other abiotic stresses. The objective of the present study was to evaluate the effect of salinity on antioxidants, antioxidant enzymes, and other markers of abiotic stress in Hyacinth bean.

\section{Materials and methods}

Plant material and chemicals

The seeds of Lablab purpureus (cv. HA-4) were procured from National Seed Project, University of Agricultural Science, GKVK, Bangalore, India. Fine chemicals and reagents were purchased from Sigma-Aldrich chemicals, Bangalore, India. All other chemicals were of analytical grade.

\section{Growth conditions}

Seeds of Lablab purpureus cultivar HA-4 were surface sterilized with $0.1 \%(\mathrm{w} / \mathrm{v})$ mercuric chloride for $1 \mathrm{~min}$, rinsed immediately with large volume of distilled water, and imbibed overnight in distilled water. The overnightsoaked seeds were sown in trays containing vermiculite and acid-washed sand $(1: 1 \mathrm{w} / \mathrm{w})$ and irrigated daily with distilled water. The germination was carried out under natural greenhouse conditions; day/night temperature and relative humidity were $30 / 25^{\circ} \mathrm{C}$, and $75 / 70 \%$, respectively. The average photoperiod was $12 \mathrm{~h}$ light/ $12 \mathrm{~h}$ dark.

Salt stress treatment and experimental design

Salt stress was induced by transferring 10-day-old seedlings of uniform size to a hydroponic system of halfstrength Hoagland medium (Allen 1968) containing different concentrations of $\mathrm{NaCl}$ along with $\mathrm{CaCl}_{2}$ corresponding to half the strength of $\mathrm{NaCl}$. Leaf and root samples were collected at 24,48 , and $72 \mathrm{~h}$ and frozen until further analysis. Plants grown on half-strength Hoagland media without $\mathrm{NaCl}$ served as control. Samples used for determination of RWC, fresh and dry weights were used immediately after collection.

The experimental design used was carried out at random factorial scheme, with 6 media regimes (control, 100, 200, $300,400,500 \mathrm{mM} \mathrm{NaCl}$ stress) and 3 evaluation points $(24,48,72$ h). Each experiment was composed of 36 experimental units (leaf + root samples) and done in triplicate.

\section{Determination of growth parameters}

Random selection of ten replicates from each treatment was done. The growth criteria measured were Leaf, shoot, and root lengths; fresh and dry weights of the whole plant.

\section{Determination of relative water content (RWC)}

The relative water content was estimated according to the method of Turner and Kramer (1980) using the equation: $\mathrm{RWC}=(\mathrm{FW}-\mathrm{DW}) \times 100 /(\mathrm{TW}-\mathrm{DW})$. Leaf disks of $10 \mathrm{~mm}$ diameter were weighed to determine the fresh weight $(\mathrm{FW})$, soaked in distilled water at $25^{\circ} \mathrm{C}$ for $4 \mathrm{~h}$ to determine the turgid weight (TW), then oven-dried at $80^{\circ} \mathrm{C}$ for $24 \mathrm{~h}$ to determine the dry weight (DW). Similarly, entire shoot and root was taken for analysis and RWC was computed as before. 


\section{Determination of Hydrogen peroxide and antioxidants}

Hydrogen peroxide content in control and stressed seedlings were determined according to Velikova et al. (2000). Leaf and root tissues $(500 \mathrm{mg}$ ) were homogenized in an ice bath with $5 \mathrm{ml}$ of $0.1 \%(\mathrm{w} / \mathrm{v})$ trichloroacetic acid. The homogenate was centrifuged at $10,000 \times g$ for $15 \mathrm{~min}$ and $0.5 \mathrm{ml}$ of the supernatant was added to $0.5 \mathrm{ml}$ of $10 \mathrm{mM}$ potassium phosphate buffer ( $\mathrm{pH} \mathrm{7.0)}$ ) and $1 \mathrm{ml}$ of $1 \mathrm{M} \mathrm{KI}$. The absorbance of the supernatant was measured at $390 \mathrm{~nm}$.

GSH was estimated according to Beutler et al. (1963). The tissue was homogenized with $3 \%$ metaphosphoric acid. DTNB [5,5'-dithiobis(2-nitrobenzoic acid)] was added to supernatants cleared by centrifugation. The formation of 5-thio-2-nitrobenzoic acid, which is proportional to total glutathione concentration, was monitored at $412 \mathrm{~nm}$ at $25^{\circ} \mathrm{C}$ against reagent controls. Ascorbic acid estimation was carried out according to the procedure of Sadasivam and Manickam (1997). The tissue was homogenized in $4 \%$ oxalic acid and centrifuged at $10,000 \times g$ for $10 \mathrm{~min}$. The assay mixture consisted of $0.1 \mathrm{ml}$ of brominated sample extract made up to $3.0 \mathrm{ml}$ with distilled water, $1.0 \mathrm{ml}$ of $2 \%$ DNPH reagent, and 1-2 drops of thiourea. After incubation at $37^{\circ} \mathrm{C}$ for $3 \mathrm{~h}$, the orange-red osazone crystals formed were dissolved by the addition of $7.0 \mathrm{ml}$ of $80 \%$ sulfuric acid and absorbance was read at $540 \mathrm{~nm}$. Total phenols were estimated by the method of Slinkard and Singleton (1977) using catechol as an authentic standard.

\section{Determination of stress response factors}

Proline content was estimated using ninhydrin reagent according to Bates et al. (1973). The amount of total soluble sugars was estimated colorimetrically at $540 \mathrm{~nm}$ using anthrone reagent according to Roe (1955). Chlorophyll content was determined according to Mackinney (1941) using acetone $(80 \%)$ extracts. The concentrations of total chlorophyll, chlorophyll-a, and -b were calculated by the formula of Arnon (1949). The extent of lipid peroxidation was determined according to Heath and Packer (1968) with suitable modification. Briefly, $0.5 \mathrm{~g}$ of fresh tissue was ground in $5.0 \mathrm{ml}$ of $0.1 \%$ TCA containing $0.5 \%$ butylated hydroxytoluene containing $1.0 \%$ PVP. The homogenate was centrifuged at $12,000 \times g$ for $30 \mathrm{~min} .4 .0 \mathrm{ml}$ of the supernatant was mixed with $4.0 \mathrm{ml}$ of the substrate $(0.5 \%$ thiobarbituric acid and 20\% TCA). The mixture was boiled for $30 \mathrm{~min}$, chilled on ice, and centrifuged at $12,000 \times \mathrm{g}$ for $10 \mathrm{~min}$. The absorbance of supernatant at $532 \mathrm{~nm}$ was measured and the nonspecific absorbance at $600 \mathrm{~nm}$ was subtracted. The MDA content was calculated from the extinction coefficient of $155 \mathrm{mM}^{-1} \mathrm{~cm}^{-1}$.

\section{Extraction of enzymes}

The frozen samples were homogenized with pre-chilled $50 \mathrm{mM}$ sodium phosphate buffer (pH 7.0) containing $5 \mathrm{mM} \beta$-mercaptoethanol and $1 \mathrm{mM}$ EDTA using pestle and mortar. L-ascorbate was raised to a final concentration of $2 \mathrm{mM}$ for extraction of APX. The homogenate was centrifuged at $12,000 \times g$ for $15 \mathrm{~min}$ at $4^{\circ} \mathrm{C}$. The supernatant was used as a source of enzymes. Soluble protein content was determined according to the method of Lowry et al. (1951) using BSA as the standard.

Assay of antioxidant enzymes

\section{Guaiacol peroxidase (POX, E.C. 1.11.1.7)}

Guaiacol peroxidase activity was measured in a reaction mixture of $3.0 \mathrm{ml}$ consisting of $50 \mathrm{mM}$ phosphate buffer (pH 7.0) containing $20 \mathrm{mM}$ guaiacol, $10 \mathrm{mM} \mathrm{H}_{2} \mathrm{O}_{2}$, and $100 \mu \mathrm{l}$ enzyme extract (Chance and Maehly 1955). The formation of tetraguaiacol was followed by an increase in $\mathrm{A}_{470} \mathrm{~nm}\left(\varepsilon=26.6 \mathrm{mM}^{-1} \mathrm{~cm}^{-1}\right)$. One unit of peroxidase is defined as the amount of enzyme needed to convert $1 \mu \mathrm{mol}$ of $\mathrm{H}_{2} \mathrm{O}_{2} \mathrm{~min}^{-1}$ at $25^{\circ} \mathrm{C}$. In-gel assay was performed by incubating the gels with $o$-dianisidine followed by $10 \mathrm{mM}$ $\mathrm{H}_{2} \mathrm{O}_{2}$ until the appearance of bands.

\section{Ascorbate peroxidase (APX, E.C. 1.11.1.11)}

The activity of APX was determined spectrophotometrically as described by Webb and Allen (1995). The assay mixture contained $50 \mathrm{mM}$ HEPES buffer ( $\mathrm{pH} 7.0$ ), $1 \mathrm{mM}$ EDTA, $1 \mathrm{mM} \mathrm{H}_{2} \mathrm{O}_{2}, 0.5 \mathrm{mM}$ sodium ascorbate, and $50 \mu \mathrm{l}$ of enzyme extract in a total volume of $2.0 \mathrm{ml}$. The reaction was initiated by addition of $\mathrm{H}_{2} \mathrm{O}_{2}$. The oxidation of ascorbate was followed by a decrease in the $\mathrm{A}_{290}$ $\left(\varepsilon=2.8 \mathrm{mM}^{-1} \mathrm{~cm}^{-1}\right)$. One unit of ascorbate peroxidase is defined as the amount of enzyme necessary to oxidize $1 \mu \mathrm{mol}$ of ascorbate per min at $25^{\circ} \mathrm{C}$.

Catalase (CAT, E.C. 1.11.1.6)

Catalase activity was assayed by following the decline in absorbance of $\mathrm{H}_{2} \mathrm{O}_{2}$ at $240 \mathrm{~nm}\left(\varepsilon=39.4 \mathrm{M}^{-1} \mathrm{~cm}^{-1}\right)$ according to the method of Aebi (1984). The reaction mixture consisted of $50 \mu \mathrm{l}$ of enzyme extract in $50 \mathrm{mM}$ sodium phosphate buffer ( $\mathrm{pH}$ 7.0). The reaction was started by addition of $\mathrm{H}_{2} \mathrm{O}_{2}$ to a final concentration of $10 \mathrm{mM}$, and its consumption was measured for $2 \mathrm{~min}$. One unit of activity is defined as the amount of enzyme that catalyzes the oxidation of $1 \mu \mathrm{mol}$ of $\mathrm{H}_{2} \mathrm{O}_{2}$ per min under the assay conditions. In-gel assay for CAT isozymes was performed by soaking the gels in $10 \mathrm{mM} \mathrm{H}_{2} \mathrm{O}_{2}$, and sequentially 
staining with $2 \%$ potassium ferricyanide followed by $2 \%$ ferric chloride to visualize the bands.

\section{Glutathione reductase (GR, E.C. 1.6.4.2)}

GR activity was determined by monitoring the oxidation of NADPH at $340 \mathrm{~nm}\left(\varepsilon=6220 \mathrm{M}^{-1} \mathrm{~cm}^{-1}\right)$ according to the method of Carlberg and Mannervik (1985). The reaction mixture contained $50 \mathrm{mM}$ Tris- $\mathrm{HCl}$ buffer ( $\mathrm{pH} 7.5), 3 \mathrm{mM}$ $\mathrm{MgCl}_{2}, 0.5 \mathrm{mM}$ GSSG, $0.2 \mathrm{mM} \mathrm{NADPH}$, and $250 \mu \mathrm{l}$ of enzyme extract in a total volume of $1.5 \mathrm{ml}$. One unit of activity is defined as the amount of enzyme that catalyzes the oxidation of $1 \mu \mathrm{mol}$ of NADPH per min under the assay conditions. GR isozymes were separated on nondenaturing gels soaked in $50 \mathrm{mM}$ Tris- $\mathrm{HCl}$ buffer $(\mathrm{pH} 7.5)$ containing $1 \mathrm{mg} / \mathrm{ml}$ MTT, $1 \mathrm{mg} / \mathrm{ml}$ 2,6-dichlorophenol indophenol, $3.4 \mathrm{nM}$ GSSG, and $0.4 \mathrm{mM}$ NADPH until the appearance of bands.

\section{Polyphenol oxidase (PPO, E.C. 1.14.18.1)}

PPO was assayed spectrophotometrically at $400 \mathrm{~nm}$ using tertiary butyl catechol as substrate according to Kanade et al. (2006). The assay mixture consisted of $0.9 \mathrm{ml}$ sodium acetate buffer (pH 5.0), $0.1 \mathrm{ml} t$-butyl catechol and $0.1 \mathrm{ml}$ enzyme extract. The quinone formed was measured at $400 \mathrm{~nm} \quad\left(\varepsilon=1150 \mathrm{M}^{-1} \mathrm{~cm}^{-1}\right)$. One unit of enzyme activity is defined as the amount of enzyme that produces $1 \mu \mathrm{mol}$ of $t$-butylquinone per minute under the assay conditions.

Assay of hydrolytic enzymes

$\beta$-Amylase (AMY, E.C. 3.2.1.1)

Activity of $\beta$-amylase was measured using the DNS method (Bernfeld 1955). The reaction mixture consisted $0.5 \mathrm{ml}$ of $2 \%$ starch solution in $50 \mathrm{mM}$ phosphate buffer $(\mathrm{pH} 7.0)$ and $0.5 \mathrm{ml}$ of enzyme extract. $\beta$-amylase isozymes were visualized by soaking the gels in substrate $(2 \%$ soluble starch) followed by incubation in $0.025 \%$ acidified iodine solution.

Acid phosphatase (AP, E.C. 3.1.3.2)

AP activity against $p$-nitrophenyl phosphate was determined by monitoring the release of $p$-nitrophenol at $410 \mathrm{~nm}$ according to Hoerling and Svensmark (1976). Each unit of activity is defined as the number of $\mu$ moles of $p$-nitro phenol released per minute. In-gel assay was carried out using $\alpha$-naphthyl phosphate as substrate and fast blue$\mathrm{RR}$ as coupling dye.
Invertase (INV, E.C. 3.2.1.26)

Invertase activity was determined by the method of Sridhar and $\mathrm{Ou}$ (1972). $4.0 \mathrm{ml}$ reaction mixture containing $0.025 \mathrm{M}$ sodium acetate buffer ( $\mathrm{pH} 5.0$ ), $0.625 \%$ sucrose, and appropriate volume of enzyme extract was incubated at $37^{\circ} \mathrm{C}$ for $24 \mathrm{~h}$. The reaction was arrested by adding equal volume of DNS reagent. The reducing sugars present were estimated using the method of Miller (1959).

Electrophoretic analysis

Non-denaturing, discontinuous slab gel electrophoresis was carried out essentially according to the method of Davis (1964). SDS-PAGE was carried out according to Laemmli (1970), employing 10\% resolving gel and 5\% stacking gel.

Statistical analysis

The experiment was performed using a randomized design. All data are expressed as means of triplicate experiments unless mentioned otherwise. Comparisons of means were performed using PrismGraph version 3.02. Data were subjected to a one-way analysis of variance (ANOVA), and the mean differences were compared by lowest standard deviations (LSD) test. Comparisons with $P \leq 0.05$ were considered significantly different.

\section{Results}

Growth parameters

Salinity stress in Lablab purpureus caused significant reduction in the growth in concentration and time-dependent manner. $\mathrm{NaCl}$ at $500 \mathrm{mM}$ caused drastic reduction in fresh and dry weights of the plant (Table 1). The plant did not show greater alteration in dry weight relative to control, while fresh weight decreased with increasing time of salinity (Table 1). The plant showed reduction in number and surface area of leaves as well as curling on exposure to salinity. Other physical features such as length of shoot, root, and leaves exhibited reduction in time and concentration dependent manner (Table 1). The effect was more pronounced in roots. RWC of leaf, shoot, and root also showed a similar relationship with concentration of $\mathrm{NaCl}$ and time of exposure (Table 1). The RWC of leaves showed steep decline at all the times of exposure up to $300 \mathrm{mM}$ and reached a plateau at 400 and $500 \mathrm{mM}$. RWC of shoots exhibited a moderate drop and that of roots showed greater decline beyond $300 \mathrm{mM}$ at all time points (Table 1). 
Table 1 Effect of salinity on morphological and physical parameters in Hyacinth bean (Lablab purpureus)

\begin{tabular}{|c|c|c|c|c|c|c|c|c|c|}
\hline \multirow[t]{2}{*}{$\mathrm{NaCl}(\mathrm{mM})$} & \multirow[t]{2}{*}{ Time (h) } & \multicolumn{3}{|l|}{ RWC (\%) } & \multicolumn{3}{|c|}{ Length (cm) } & \multicolumn{2}{|l|}{ Weight (g) } \\
\hline & & Leaf & Stem & Root & Leaf & Stem & Root & Fresh & Dry \\
\hline \multirow[t]{3}{*}{ Control } & 24 & $87.6 \pm 0.5$ & $87.7 \pm 1.6$ & $89.9 \pm 0.0$ & $3.3 \pm 0.8$ & $6.2 \pm 0.5$ & $0.8 \pm 0.3$ & $0.73 \pm 0.07$ & $0.09 \pm 0.01$ \\
\hline & 48 & $85.9 \pm 1.7$ & $86.5 \pm 0.9$ & $89.0 \pm 0.5$ & $3.7 \pm 0.5$ & $6.9 \pm 0.8$ & $1.6 \pm 0.9$ & $1.04 \pm 0.04$ & $0.10 \pm 0.02$ \\
\hline & 72 & $78.3 \pm 2.4$ & $85.3 \pm 1.5$ & $88.8 \pm 0.8$ & $4.6 \pm 0.2$ & $7.2 \pm 0.4$ & $2.7 \pm 0.9$ & $1.27 \pm 0.10$ & $0.11 \pm 0.01$ \\
\hline \multirow[t]{3}{*}{$100 \mathrm{mM}$} & 24 & $75.9 \pm 2.1$ & $84.3 \pm 2.2$ & $85.6 \pm 4.0$ & $2.6 \pm 0.9$ & $5.8 \pm 0.2$ & $0.9 \pm 0.5$ & $0.87 \pm 0.08$ & $0.12 \pm 0.06$ \\
\hline & 48 & $73.3 \pm 1.6$ & $76.9 \pm 3.0$ & $86.4 \pm 0.9$ & $3.2 \pm 0.3$ & $6.0 \pm 0.1$ & $0.9 \pm 0.4$ & $1.08 \pm 0.10$ & $0.09 \pm 0.00$ \\
\hline & 72 & $61.9 \pm 1.6$ & $74.9 \pm 0.8$ & $87.0 \pm 0.6$ & $4.1 \pm 0.7$ & $6.3 \pm 1.3$ & $1.0 \pm 0.5$ & $1.27 \pm 0.14$ & $0.08 \pm 0.03$ \\
\hline \multirow[t]{3}{*}{$200 \mathrm{mM}$} & 24 & $66.2 \pm 5.7$ & $82.4 \pm 1.7$ & $83.3 \pm 2.3$ & $2.3 \pm 0.6$ & $5.7 \pm 1.2$ & $0.7 \pm 0.3$ & $0.91 \pm 0.08$ & $0.12 \pm 0.02$ \\
\hline & 48 & $60.9 \pm 4.4$ & $74.8 \pm 1.6$ & $81.4 \pm 3.4$ & $2.6 \pm 0.5$ & $6.0 \pm 0.6$ & $0.7 \pm 0.4$ & $1.02 \pm 0.06$ & $0.09 \pm 0.02$ \\
\hline & 72 & $51.5 \pm 2.5$ & $68.9 \pm 2.0$ & $80.8 \pm 4.3$ & $2.7 \pm 0.5$ & $6.2 \pm 1.1$ & $0.8 \pm 0.2$ & $1.10 \pm 0.08$ & $0.08 \pm 0.07$ \\
\hline \multirow[t]{3}{*}{$300 \mathrm{mM}$} & 24 & $56.6 \pm 2.2$ & $81.0 \pm 3.0$ & $81.4 \pm 4.5$ & $2.4 \pm 0.5$ & $5.1 \pm 0.7$ & $0.8 \pm 0.3$ & $0.80 \pm 0.06$ & $0.11 \pm 0.01$ \\
\hline & 48 & $51.8 \pm 4.8$ & $74.3 \pm 2.7$ & $77.1 \pm 4.2$ & $2.4 \pm 0.8$ & $5.3 \pm 1.0$ & $0.8 \pm 0.2$ & $0.81 \pm 0.06$ & $0.09 \pm 0.08$ \\
\hline & 72 & $45.9 \pm 4.5$ & $67.5 \pm 3.7$ & $70.2 \pm 3.1$ & $2.7 \pm 0.6$ & $5.3 \pm 0.8$ & $0.9 \pm 0.6$ & $0.82 \pm 0.07$ & $0.08 \pm 0.07$ \\
\hline \multirow[t]{3}{*}{$400 \mathrm{mM}$} & 24 & $54.5 \pm 5.2$ & $76.9 \pm 2.3$ & $74.5 \pm 4.7$ & $2.3 \pm 0.4$ & $4.7 \pm 0.8$ & $0.7 \pm 0.1$ & $0.72 \pm 0.06$ & $0.11 \pm 0.01$ \\
\hline & 48 & $50.4 \pm 2.7$ & $69.3 \pm 2.0$ & $68.2 \pm 1.1$ & $2.4 \pm 0.5$ & $4.7 \pm 0.9$ & $0.7 \pm 0.4$ & $0.74 \pm 0.05$ & $0.08 \pm 0.06$ \\
\hline & 72 & $44.6 \pm 0.8$ & $64.6 \pm 5.2$ & $57.1 \pm 4.2$ & $2.4 \pm 0.5$ & $4.7 \pm 1.0$ & $0.7 \pm 0.0$ & $0.76 \pm 0.05$ & $0.07 \pm 0.05$ \\
\hline \multirow[t]{3}{*}{$500 \mathrm{mM}$} & 24 & $53.0 \pm 2.7$ & $70.1 \pm 2.3$ & $70.0 \pm 1.2$ & $2.3 \pm 0.7$ & $4.1 \pm 0.2$ & $0.6 \pm 1.0$ & $0.52 \pm 0.06$ & $0.10 \pm 0.02$ \\
\hline & 48 & $51.2 \pm 4.4$ & $65.4 \pm 1.8$ & $63.4 \pm 5.3$ & $2.3 \pm 0.4$ & $4.1 \pm 0.4$ & $0.6 \pm 1.0$ & $0.53 \pm 0.06$ & $0.07 \pm 0.06$ \\
\hline & 72 & $43.5 \pm 7.5$ & $56.7 \pm 4.6$ & $52.1 \pm 0.2$ & $2.3 \pm 0.3$ & $4.1 \pm 0.2$ & $0.6 \pm 0.8$ & $0.54 \pm 0.07$ & $0.06 \pm 0.02$ \\
\hline
\end{tabular}

Seedlings of Dolichos were salt-stressed for $24-72 \mathrm{~h}$ with $\mathrm{NaCl}(100-500 \mathrm{mM})$ and individual seedlings were analyzed for determination of length, RWC, and weight. Five seedlings from each treatment were analyzed. Values are \pm SE

\section{Stress markers}

The salt stress resulted in increased production of $\mathrm{H}_{2} \mathrm{O}_{2}$ in time- and concentration-dependent manner. Lablab purpureus exposed to $\mathrm{NaCl}$ at 300 and $400 \mathrm{mM}$ for 48 and $72 \mathrm{~h}$ showed greater increase in $\mathrm{H}_{2} \mathrm{O}_{2}$ (Table 2). In general, the $\mathrm{H}_{2} \mathrm{O}_{2}$ levels were significantly elevated at $48 \mathrm{~h}$ of exposure under all concentrations. The $\mathrm{H}_{2} \mathrm{O}_{2}$ level in roots showed significant elevation beyond $200 \mathrm{mM} \mathrm{NaCl}$ at $48 \mathrm{~h}$ of exposure. However, the exposure for $72 \mathrm{~h}$ showed a steep decline in $\mathrm{H}_{2} \mathrm{O}_{2}$ levels beyond $300 \mathrm{mM} \mathrm{NaCl}$ (Table 2).

Reduced glutathione levels in leaves showed a significant elevation between $300-500 \mathrm{mM}$ at $48 \mathrm{~h}$ of exposure (Table 3). On the contrary, roots showed a reduction in GSH levels proportionate to both concentrations of $\mathrm{NaCl}$ and time of exposure (Table 3).

The antioxidant ascorbic acid levels in leaves showed an exponential increase with concentration at $48 \mathrm{~h}$ of exposure (Table 3). This relationship was not seen during 24 and $72 \mathrm{~h}$ of exposure (Table 2). In roots, the ascorbate levels increased in a concentration-dependent manner at all the time points, and the gradation was clearer at 24 and $72 \mathrm{~h}$ of exposure (Table 3).

The osmolyte proline levels in leaves were elevated under salt stress. The effect was moderate up to $300 \mathrm{mM}$ during the entire period of exposure. However, $400 \mathrm{mM}$
$\mathrm{NaCl}$ showed a twofold increase in proline at $48 \mathrm{~h}$ while $500 \mathrm{mM}$ exhibited a 2.5-fold rise at $72 \mathrm{~h}$ of exposure (Table 2). The proline levels in roots did not show any significant rise (Table 2).

MDA content of salt-stressed leaves of Lablab purpureus exhibited time- and concentration-dependent elevation up to $300 \mathrm{mM}$. However, this relationship did not hold well for 400 and $500 \mathrm{mM} \mathrm{NaCl}$, although the levels doubled at $72 \mathrm{~h}$ of exposure (Table 2). The MDA level in roots showed a marginal rise in time- and concentration-dependent manner. Beyond $200 \mathrm{mM} \mathrm{NaCl}$, a threefold increase in MDA levels was observed for $72 \mathrm{~h}$ of exposure (Table 2).

Total soluble sugar content of the salt-stressed plant leaves did not show significant alteration throughout the duration of exposure up to $200 \mathrm{mM} \mathrm{NaCl}$. However, beyond $300 \mathrm{mM}$, the levels showed considerable elevation at $24 \mathrm{~h}$ of exposure, and declined after 48 and $72 \mathrm{~h}$ (Table 2). The levels in roots did not show much alteration, except for a marginal increase under 300 and $400 \mathrm{mM}$ $\mathrm{NaCl}$ at 24 and $48 \mathrm{~h}$ of exposure (Table 2).

The total phenol content of the salt-stressed leaves exhibited a concentration-dependent increase from 100$400 \mathrm{mM} \mathrm{NaCl}$ during the first $24 \mathrm{~h}$ of exposure. However, the levels showed a marginal rise under all concentrations employed during 48 and $72 \mathrm{~h}$ (Table 3). Contrary to leaves, the total phenols in roots showed a decline in 
Table 2 Levels of typical stress markers in leaves and roots of salinity-stressed Hyacinth bean (Lablab purpureus)

\begin{tabular}{|c|c|c|c|c|c|c|c|c|}
\hline \multirow[t]{2}{*}{ Tissue } & \multirow[t]{2}{*}{ Time } & \multirow[t]{2}{*}{ Stress marker } & \multicolumn{6}{|c|}{ Concentration of $\mathrm{NaCl}$} \\
\hline & & & Control & $100 \mathrm{mM}$ & $200 \mathrm{mM}$ & $300 \mathrm{mM}$ & $400 \mathrm{mM}$ & $500 \mathrm{mM}$ \\
\hline \multirow[t]{15}{*}{ Leaf } & \multirow[t]{5}{*}{$24 \mathrm{~h}$} & $\mathrm{H}_{2} \mathrm{O}_{2}^{\mathrm{a}}$ & $3.60 \pm 1.4$ & $8.32 \pm 0.6$ & $11.8 \pm 0.4$ & $16.2 \pm 0.5$ & $17.4 \pm 1.4$ & $22.1 \pm 1.7$ \\
\hline & & Proline $^{\mathrm{b}}$ & $0.59 \pm 0.2$ & $0.77 \pm 0.3$ & $0.94 \pm 0.5$ & $0.84 \pm 0.1$ & $0.78 \pm 0.3$ & $0.86 \pm 0.3$ \\
\hline & & $\mathrm{MDA}^{\mathrm{c}}$ & $4.85 \pm 0.12$ & $5.81 \pm 0.47$ & $7.82 \pm 0.25$ & $8.03 \pm 0.69$ & $7.43 \pm 0.64$ & $7.24 \pm 0.22$ \\
\hline & & Total Chlorophyll $^{\mathrm{b}}$ & $14.49 \pm 1.4$ & $12.51 \pm 1.3$ & $9.99 \pm 1.2$ & $9.13 \pm 1.1$ & $7.79 \pm 1.1$ & $7.46 \pm 0.9$ \\
\hline & & Total Soluble Sugars ${ }^{\mathrm{b}}$ & $19.72 \pm 1.5$ & $21.83 \pm 0.3$ & $24.91 \pm 0.6$ & $27.37 \pm 1.5$ & $30.57 \pm 2.3$ & $31.43 \pm 1.1$ \\
\hline & \multirow[t]{5}{*}{$48 \mathrm{~h}$} & $\mathrm{H}_{2} \mathrm{O}_{2}^{\mathrm{a}}$ & $9.50 \pm 0.4$ & $14.2 \pm 2.2$ & $15.9 \pm 1.0$ & $29.8 \pm 2.8$ & $44.4 \pm 1.7$ & $31.0 \pm 0.9$ \\
\hline & & Proline $^{\mathrm{b}}$ & $0.81 \pm 0.4$ & $1.18 \pm 0.1$ & $1.14 \pm 0.4$ & $1.23 \pm 0.5$ & $1.60 \pm 0.12$ & $1.28 \pm 0.9$ \\
\hline & & $\mathrm{MDA}^{\mathrm{c}}$ & $5.46 \pm 0.3$ & $7.94 \pm 0.9$ & $11.62 \pm 1.3$ & $11.16 \pm 1.2$ & $9.15 \pm 1.4$ & $7.83 \pm 0.6$ \\
\hline & & Total Chlorophyll $^{\mathrm{b}}$ & $13.07 \pm 1.3$ & $10.71 \pm 0.7$ & $10.43 \pm 0.7$ & $8.82 \pm 0.7$ & $7.88 \pm 0.9$ & $6.62 \pm 0.6$ \\
\hline & & Total Soluble Sugars ${ }^{\mathrm{b}}$ & $20.28 \pm 1.3$ & $25.17 \pm 0.9$ & $23.39 \pm 1.4$ & $21.67 \pm 1.7$ & $21.42 \pm 1.8$ & $19.45 \pm 0.5$ \\
\hline & \multirow[t]{5}{*}{$72 \mathrm{~h}$} & $\mathrm{H}_{2} \mathrm{O}_{2}^{\mathrm{a}}$ & $8.61 \pm 0.4$ & $7.51 \pm 0.6$ & $22.5 \pm 1.2$ & $32.9 \pm 1.7$ & $23.5 \pm 1.4$ & $22.7 \pm 1.0$ \\
\hline & & Proline $^{\mathrm{b}}$ & $0.71 \pm 0.1$ & $1.17 \pm 0.4$ & $1.20 \pm 0.7$ & $1.21 \pm 0.08$ & $1.30 \pm 0.16$ & $1.71 \pm 0.2$ \\
\hline & & $\mathrm{MDA}^{\mathrm{c}}$ & $7.88 \pm 0.8$ & $13.47 \pm 0.7$ & $17.51 \pm 0.8$ & $16.10 \pm 0.8$ & $13.23 \pm 0.6$ & $13.20 \pm 1.3$ \\
\hline & & Total Chlorophyll & $11.53 \pm 0.4$ & $8.68 \pm 0.4$ & $8.47 \pm 0.4$ & $7.71 \pm 0.1$ & $7.51 \pm 0.4$ & $5.65 \pm 0.9$ \\
\hline & & Total Soluble Sugars ${ }^{\mathrm{b}}$ & $20.77 \pm 1.4$ & $24.41 \pm 0.7$ & $21.30 \pm 0.6$ & $19.67 \pm 0.7$ & $17.71 \pm 1.4$ & $15.01 \pm 1.3$ \\
\hline \multirow[t]{12}{*}{ Root } & \multirow[t]{4}{*}{$24 \mathrm{~h}$} & $\mathrm{H}_{2} \mathrm{O}_{2}^{\mathrm{a}}$ & $26.0 \pm 1.2$ & $25.0 \pm 3.1$ & $41.0 \pm 0.4$ & $44.0 \pm 2.4$ & $38.0 \pm 2.0$ & $38.0 \pm 2.3$ \\
\hline & & Proline $^{\mathrm{b}}$ & $0.52 \pm 0.1$ & $0.60 \pm 0.07$ & $0.60 \pm 0.2$ & $0.70 \pm 0.2$ & $0.62 \pm 0.1$ & $0.56 \pm 0.3$ \\
\hline & & $\mathrm{MDA}^{\mathrm{c}}$ & $2.26 \pm 0.2$ & $3.29 \pm 0.3$ & $3.22 \pm 0.4$ & $3.34 \pm 0.3$ & $3.95 \pm 0.5$ & $4.09 \pm 0.3$ \\
\hline & & Total Soluble Sugars $^{\mathrm{b}}$ & $25.90 \pm 0.7$ & $27.73 \pm 2.3$ & $29.76 \pm 0.03$ & $37.81 \pm 2.1$ & $35.58 \pm 1.8$ & $29.42 \pm 0.4$ \\
\hline & \multirow[t]{4}{*}{$48 \mathrm{~h}$} & $\mathrm{H}_{2} \mathrm{O}_{2}^{\mathrm{a}}$ & $26.0 \pm 2.7$ & $27.0 \pm 3.0$ & $45.0 \pm 2.8$ & $57.0 \pm 0.8$ & $53.0 \pm 1.1$ & $57.0 \pm 2.1$ \\
\hline & & Proline $^{\mathrm{b}}$ & $0.56 \pm 0.3$ & $0.71 \pm 0.1$ & $0.74 \pm 0.2$ & $0.75 \pm 0.1$ & $0.70 \pm 0.05$ & $0.64 \pm 0.2$ \\
\hline & & $\mathrm{MDA}^{\mathrm{c}}$ & $2.89 \pm 0.3$ & $3.62 \pm 0.3$ & $3.67 \pm 0.6$ & $3.33 \pm 0.3$ & $4.71 \pm 0.5$ & $4.71 \pm 0.6$ \\
\hline & & Total Soluble Sugars ${ }^{\mathrm{b}}$ & $27.19 \pm 0.7$ & $27.60 \pm 2.2$ & $29.83 \pm 0.9$ & $35.09 \pm 0.8$ & $32.19 \pm 1.6$ & $29.50 \pm 2.3$ \\
\hline & \multirow[t]{4}{*}{$72 \mathrm{~h}$} & $\mathrm{H}_{2} \mathrm{O}_{2}^{\mathrm{a}}$ & $19.0 \pm 1.8$ & $18.0 \pm 3.8$ & $63.0 \pm 2.4$ & $8.00 \pm 0.8$ & $3.00 \pm 0.6$ & $1.00 \pm 0.3$ \\
\hline & & Proline $^{\mathrm{b}}$ & $0.48 \pm 0.1$ & $0.59 \pm 0.3$ & $0.66 \pm 0.2$ & $0.67 \pm 0.2$ & $0.64 \pm 0.2$ & $0.58 \pm 0.3$ \\
\hline & & $\mathrm{MDA}^{\mathrm{c}}$ & $3.21 \pm 0.1$ & $5.26 \pm 0.3$ & $8.34 \pm 0.3$ & $7.51 \pm 0.4$ & $8.44 \pm 0.6$ & $8.57 \pm 0.6$ \\
\hline & & Total Soluble Sugars ${ }^{\mathrm{b}}$ & $28.08 \pm 1.5$ & $30.72 \pm 1.8$ & $34.13 \pm 0.8$ & $35.53 \pm 0.7$ & $30.78 \pm 0.7$ & $27.58 \pm 1.5$ \\
\hline
\end{tabular}

a $\mu \mathrm{g} / \mathrm{g}$ fresh weight tissue

b $\mathrm{mg} / \mathrm{g}$ fresh weight tissue

c $\mathrm{m}$ moles/g fresh weight tissue

concentration and time-dependent manner. However, the gradation and decrement were not steep (Table 3). Total chlorophyll content in leaves exhibited a time- and concentration-dependent decline (Table 2).

\section{Enzyme activities}

Levels of antioxidant enzyme POX in salt-stressed leaves exhibited time- and concentration-dependent elevation up to $300 \mathrm{mM} \mathrm{NaCl}$. However, the levels were not commensurate with concentration at 400 and $500 \mathrm{mM} \mathrm{NaCl}$ (Fig. 1a). The intensity of the POX isozymes during the exposure also matched the activity profile of enzymes (Fig. 1a). Salinity stress did not affect in vitro levels and isozyme intensities of POX in root, except at $100 \mathrm{mM}$ $\mathrm{NaCl}$ during $24 \mathrm{~h}$ of exposure (Fig. 1b). APX too showed a time- and concentration-dependent increase in leaves but decreased slightly in roots at concentrations above $300 \mathrm{mM}$ (Fig. 6).

CAT activity in salt-stressed Lablab purpureus leaves showed a $75 \%$ decline during the entire period of stress. The decline was more severe at higher concentrations of $\mathrm{NaCl}$ reaching almost $5 \%$ of control at $500 \mathrm{mM} \mathrm{NaCl}$. The isozyme pattern and band intensity also correlated with the in vitro levels (Fig. 2a, b).

GR activity showed a concentration-dependent increase up to $400 \mathrm{mM}$ in leaves. However, the rise was not in linear relationship with time. The enzyme levels reached highest values at 300 and $400 \mathrm{mM} \mathrm{NaCl}$, albeit the levels being slightly higher than controls at $500 \mathrm{mM}$. This in vitro pattern also correlated with band intensity of the enzymes in in-gel assay (Fig. 3a). The GR levels in roots exhibited a 
Table 3 Levels of non-enzymatic antioxidants in leaves and roots of salinity-stressed Hyacinth bean (Lablab purpureus)

\begin{tabular}{|c|c|c|c|c|c|c|c|c|}
\hline \multirow[t]{2}{*}{ Sample } & \multirow[t]{2}{*}{ Time } & \multirow[t]{2}{*}{ Antioxidants } & \multicolumn{6}{|c|}{ Concentration of $\mathrm{NaCl}$} \\
\hline & & & Control & $100 \mathrm{mM}$ & $200 \mathrm{mM}$ & $300 \mathrm{mM}$ & $400 \mathrm{mM}$ & $500 \mathrm{mM}$ \\
\hline \multirow[t]{9}{*}{ Leaf } & \multirow[t]{3}{*}{$24 \mathrm{~h}$} & $\mathrm{GSH}^{\mathrm{a}}$ & $19.0 \pm 3.1$ & $49.4 \pm 2.0$ & $90.3 \pm 9.4$ & $155.3 \pm 13.6$ & $132.5 \pm 3.6$ & $115.9 \pm 3.6$ \\
\hline & & Ascorbate $^{\mathrm{b}}$ & $96.7 \pm 8.9$ & $100.4 \pm 10.7$ & $106.0 \pm 12.3$ & $110.1 \pm 14.1$ & $113.5 \pm 14.0$ & $119.8 \pm 14.7$ \\
\hline & & Total Phenols ${ }^{\mathrm{b}}$ & $2.21 \pm 0.1$ & $2.62 \pm 0.2$ & $2.94 \pm 0.2$ & $3.42 \pm 0.3$ & $3.81 \pm 0.09$ & $2.92 \pm 0.4$ \\
\hline & \multirow[t]{3}{*}{$48 \mathrm{~h}$} & $\mathrm{GSH}^{\mathrm{a}}$ & $20.2 \pm 4.0$ & $81.9 \pm 5.3$ & $105.3 \pm 7.6$ & $187.3 \pm 7.5$ & $196.6 \pm 1.8$ & $177.1 \pm 3.5$ \\
\hline & & Ascorbate $^{\mathrm{b}}$ & $103.7 \pm 4.2$ & $136.7 \pm 10.3$ & $169.8 \pm 7.5$ & $192.8 \pm 6.1$ & $219.3 \pm 9.5$ & $250.2 \pm 3.9$ \\
\hline & & Total Phenols ${ }^{\mathrm{b}}$ & $2.31 \pm 0.2$ & $2.54 \pm 0.2$ & $2.60 \pm 0.1$ & $2.77 \pm 0.1$ & $3.04 \pm 0.05$ & $3.43 \pm 0.2$ \\
\hline & \multirow[t]{3}{*}{$72 \mathrm{~h}$} & $\mathrm{GSH}^{\mathrm{a}}$ & $26.1 \pm 4.8$ & $125.6 \pm 5.8$ & $129.0 \pm 14.4$ & $150.9 \pm 9.3$ & $170.8 \pm 5.1$ & $90.3 \pm 9.6$ \\
\hline & & Ascorbate $^{\mathrm{b}}$ & $121.4 \pm 7.7$ & $232.4 \pm 10.5$ & $288.5 \pm 13.0$ & $278.0 \pm 14.6$ & $291.7 \pm 5.7$ & $290.6 \pm 5.9$ \\
\hline & & Total Phenols ${ }^{\mathrm{b}}$ & $2.12 \pm 0.06$ & $2.20 \pm 0.06$ & $2.51 \pm 0.08$ & $2.63 \pm 0.01$ & $3.15 \pm 0.07$ & $3.25 \pm 0.04$ \\
\hline \multirow[t]{9}{*}{ Root } & \multirow[t]{3}{*}{$24 \mathrm{~h}$} & $\mathrm{GSH}^{\mathrm{a}}$ & $13.2 \pm 1.0$ & $41.8 \pm 2.2$ & $41.0 \pm 0.8$ & $58.7 \pm 1.9$ & $43.1 \pm 2.7$ & $28.1 \pm 2.6$ \\
\hline & & Ascorbate $^{\mathrm{b}}$ & $35.9 \pm 3.6$ & $39.3 \pm 2.0$ & $48.5 \pm 3.6$ & $57.4 \pm 2.5$ & $68.4 \pm 5.5$ & $73.0 \pm 4.9$ \\
\hline & & Total Phenols ${ }^{\mathrm{b}}$ & $0.41 \pm 0.01$ & $0.47 \pm 0.05$ & $0.41 \pm 0.01$ & $0.34 \pm 0.02$ & $0.27 \pm 0.008$ & $0.24 \pm 0.07$ \\
\hline & \multirow[t]{3}{*}{$48 \mathrm{~h}$} & $\mathrm{GSH}^{\mathrm{a}}$ & $12.5 \pm 0.5$ & $47.7 \pm 3.3$ & $49.7 \pm 2.1$ & $30.3 \pm 0.8$ & $22.1 \pm 1.6$ & $18.0 \pm 2.9$ \\
\hline & & Ascorbate ${ }^{\mathrm{b}}$ & $60.8 \pm 10.0$ & $70.8 \pm 10.0$ & $95.1 \pm 3.7$ & $108.0 \pm 6.1$ & $112.3 \pm 6.9$ & $122.4 \pm 5.0$ \\
\hline & & Total Phenols ${ }^{\mathrm{b}}$ & $0.48 \pm 0.02$ & $0.46 \pm 0.02$ & $0.40 \pm 0.01$ & $0.36 \pm 0.02$ & $0.33 \pm 0.01$ & $0.29 \pm 0.01$ \\
\hline & \multirow[t]{3}{*}{$72 \mathrm{~h}$} & $\mathrm{GSH}^{\mathrm{a}}$ & $12.3 \pm 1.5$ & $34.1 \pm 1.9$ & $17.4 \pm 0.5$ & $16.4 \pm 0.4$ & $13.2 \pm 1.2$ & $6.2 \pm 3.1$ \\
\hline & & Ascorbate $^{\mathrm{b}}$ & $63.2 \pm 8.0$ & $113.2 \pm 3.0$ & $125.4 \pm 3.6$ & $158.5 \pm 5.1$ & $165.7 \pm 8.3$ & $175.0 \pm 2.5$ \\
\hline & & Total Phenols ${ }^{\mathrm{b}}$ & $0.47 \pm 0.01$ & $0.45 \pm 0.01$ & $0.38 \pm 0.02$ & $0.34 \pm 0.02$ & $0.25 \pm 0.02$ & $0.21 \pm 0.04$ \\
\hline
\end{tabular}

${ }^{a} \mu \mathrm{g} / \mathrm{g}$ fresh weight tissue

b $\mathrm{mg} / \mathrm{g}$ fresh weight tissue

Fig. 1 Levels of guaiacol peroxidase in leaf (a) and root (b) of Lablab purpureus during salt stress. Results are mean $\pm \mathrm{SE}(P<0.05)$ obtained from three replicates Lower panel Zymogram of POX during salt stress; $100 \mu \mathrm{g}$ protein of each sample (48 h control and treated) was separated on non-denaturing PAGE (12\%) and stained for enzymes as described in "Materials and methods"
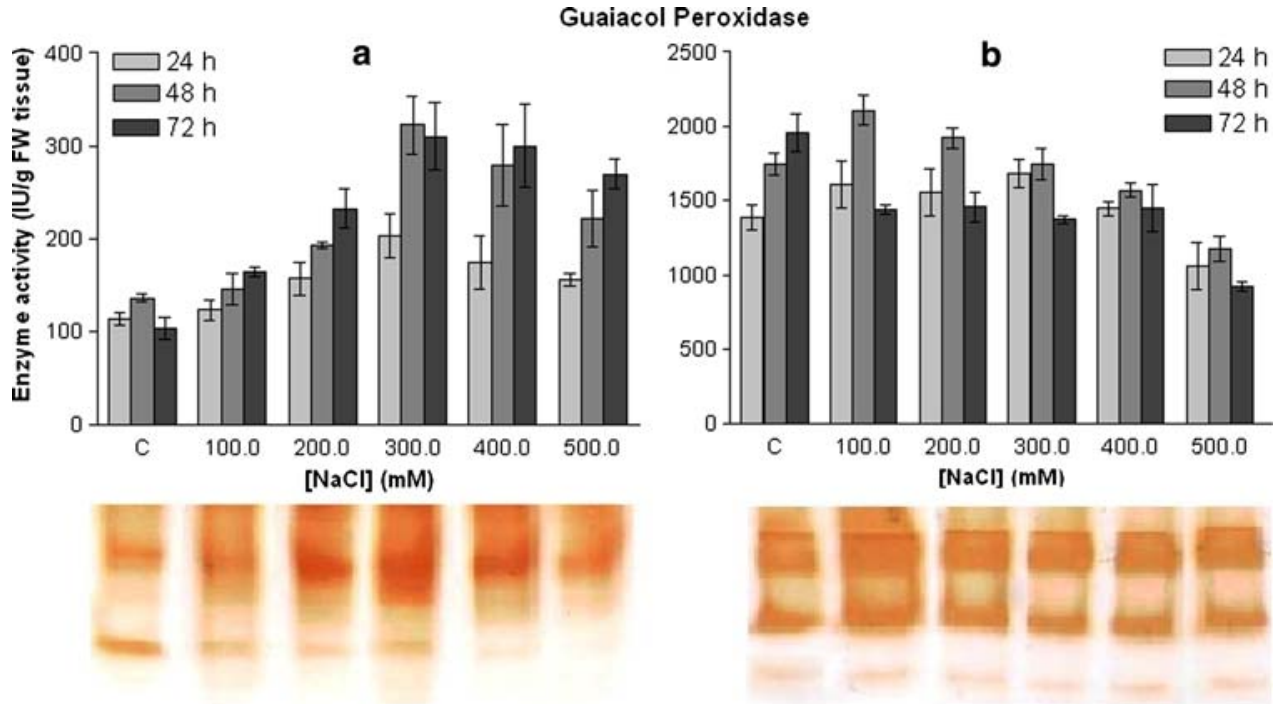

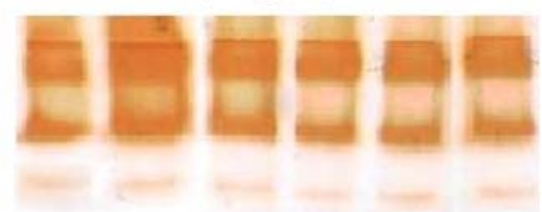

general inverse relationship with increasing concentration of $\mathrm{NaCl}$ and time of exposure, as ascertained by in vitro and in-gel assays (Fig. 3b).

Hydrolytic enzyme $\beta$-amylase in stressed Lablab leaves showed a pronounced increase in activity up to $300 \mathrm{mM}$ $\mathrm{NaCl}$, followed by a gradual decline with increasing concentration (Fig. 4a). Roots exhibited a decrease at all concentrations, except at initial $100 \mathrm{mM} \mathrm{NaCl}$ in a timeindependent manner (Fig. 4b).
Acid phosphatase activity in leaves exhibited a significant and gradual decrease during the entire duration of stress and concentration regimes (Fig. 5a). On the contrary, the enzyme levels in roots showed a positive correlation up to $300 \mathrm{mM} \mathrm{NaCl}$ and disappeared beyond $300 \mathrm{mM}$ (Fig. 5b).

Invertase activity in both leaves and roots showed a clear decrease in response to increasing concentration of $\mathrm{NaCl}$. The enzyme levels and time of exposure in leaves 
Fig. 2 Levels of catalase in leaf (a) and root (b) of Lablab purpureus during salt stress. Results are mean $\pm \mathrm{SE}$ $(P<0.05)$, obtained from three replicates Lower panel Zymogram of CAT during salt stress; $100 \mu \mathrm{g}$ protein of each sample (48 $\mathrm{h}$ control and treated) was separated on nondenaturing PAGE $(12 \%)$ and stained for enzymes as described in "Materials and methods"

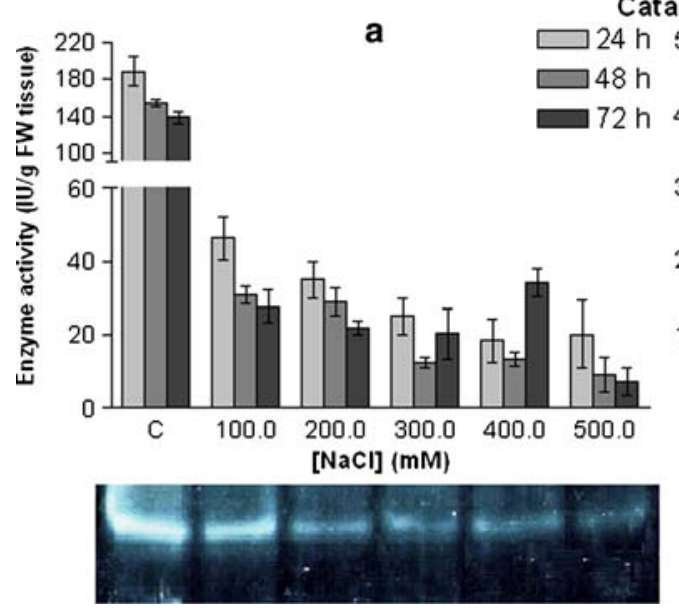

Catalase

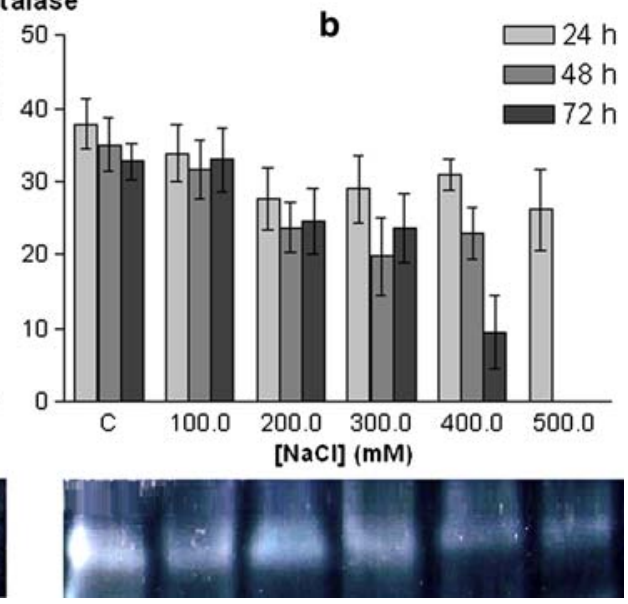

Fig. 3 Levels of glutathione reductase in leaf (a) and root (b) of Lablab purpureus during salt stress. Results are mean $\pm \mathrm{SE}$ $(P<0.05)$, obtained from three replicates Lower panel Zymogram of GR during salt stress; $100 \mu \mathrm{g}$ protein of each sample (48 $\mathrm{h}$ control and treated) was separated on nondenaturing PAGE (12\%) and stained for enzymes as described in "Materials and methods"
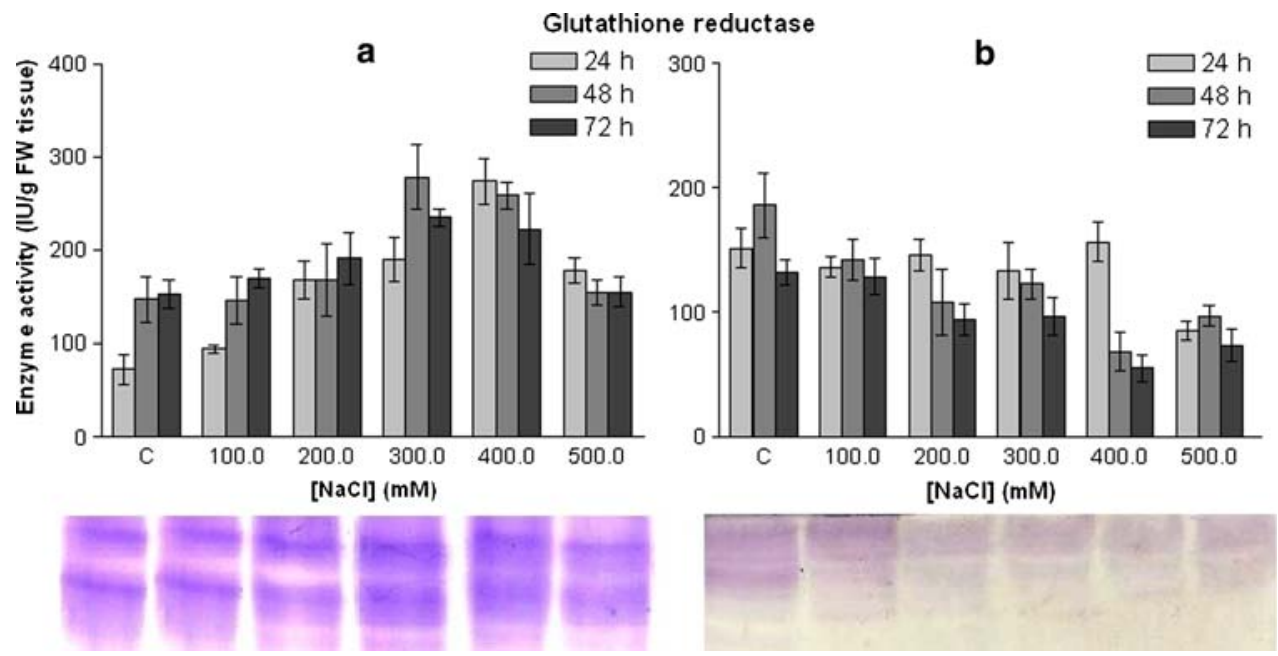

Fig. 4 Levels of amylase activity in leaf (a) and root (b) of Lablab purpureus during salt stress. Results are mean $\pm \mathrm{SE}$ $(P<0.05)$, obtained from three replicates Lower panel Zymogram of AMY during salt stress; $100 \mu \mathrm{g}$ protein of each sample $(24 \mathrm{~h}$ control and treated) was separated on nondenaturing PAGE $(12 \%)$ and stained for enzymes as described in "Materials and methods"

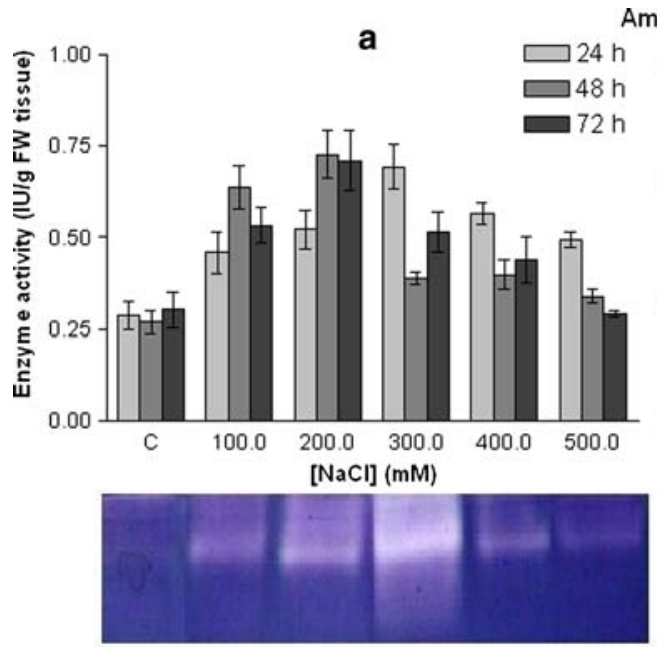

Amylase

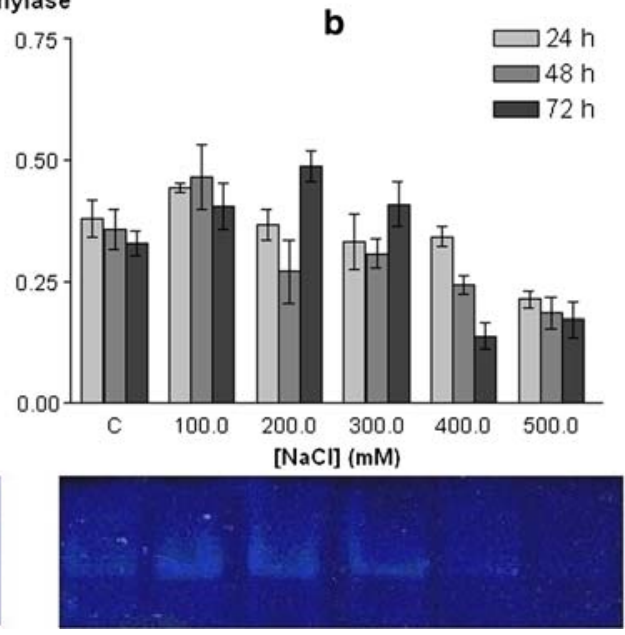

and roots did not show any relationship (Fig. 6). PPO activity in leaves and roots too increased up to $200 \mathrm{mM}$ $\mathrm{NaCl}$ and decreased beyond $200 \mathrm{mM}$ (Fig. 6).
SDS-PAGE patterns of the leaves exposed to different concentration of $\mathrm{NaCl}$ showed no remarkable alterations in protein band pattern with time of exposure or concentration 
Fig. 5 Levels of acid phosphatase activity levels in leaf (a) and root (b) of Lablab purpureus during salt stress.

Results are mean $\pm \mathrm{SE}$

$(P<0.05)$, obtained from three replicates Lower panel

Zymogram of AP during salt stress; $100 \mu \mathrm{g}$ protein of each sample (48 $\mathrm{h}$ control and treated) was separated on nondenaturing PAGE (10\%) and stained for enzymes as described under "Materials and methods"

Fig. 6 Levels of ascorbate peroxidase, invertase, and polyphenol oxidase in leaf and roots of Lablab purpureus during salt stress. Results are mean $\pm \mathrm{SE}(P<0.05)$, obtained from three replicates

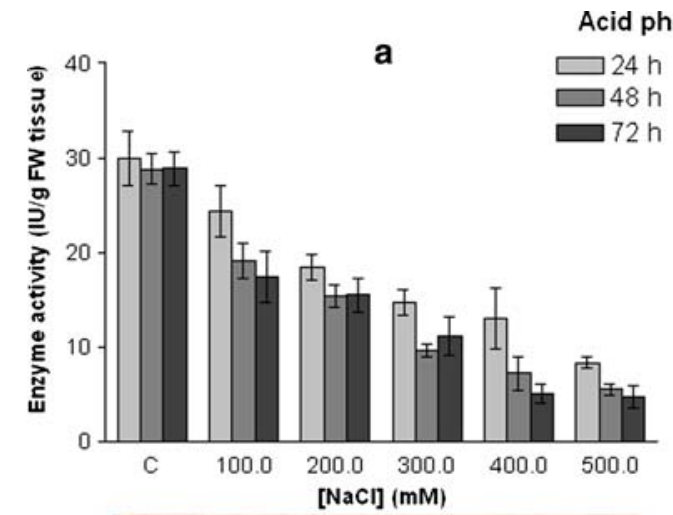

Acid phosphatase
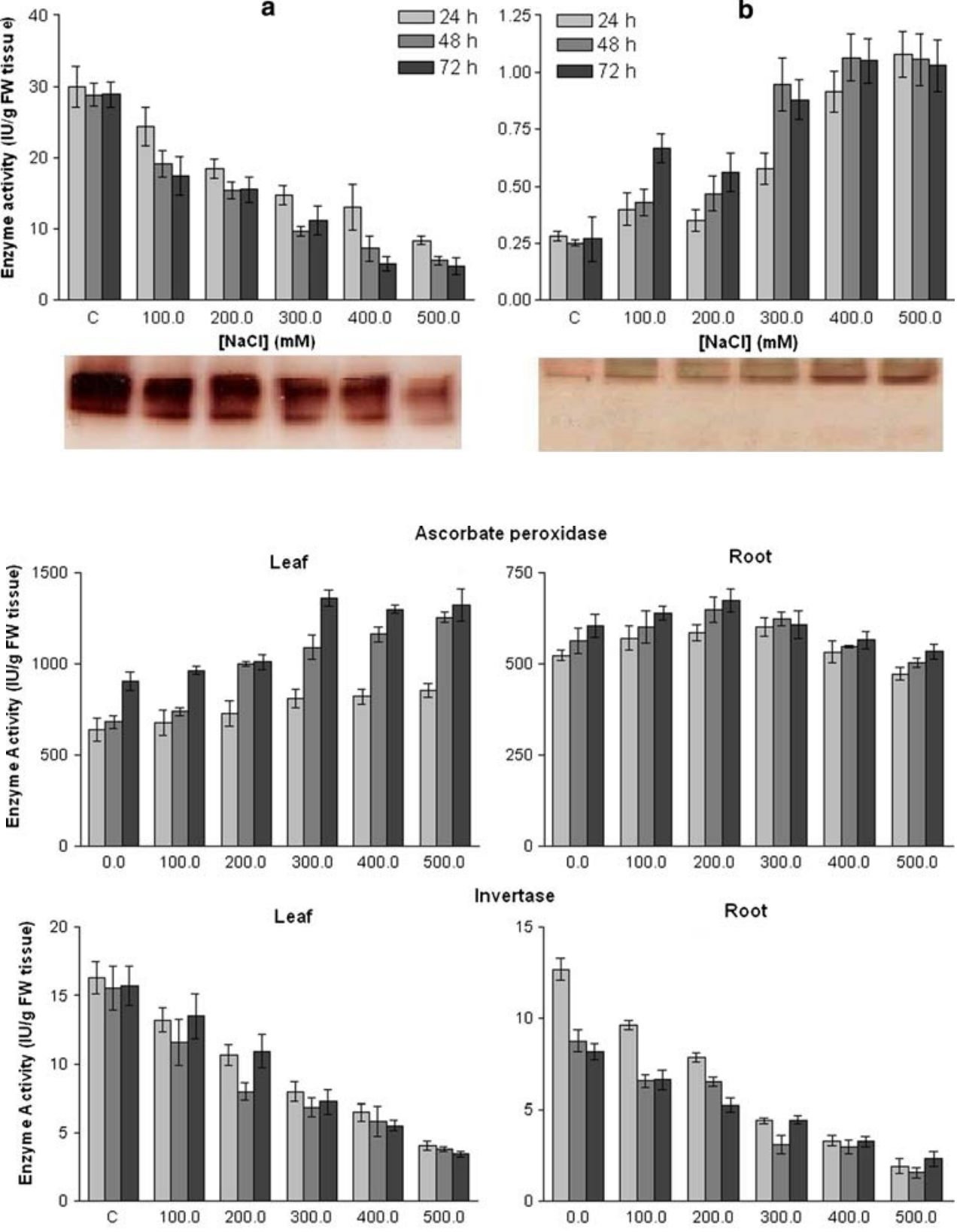

Polyphenol oxidase
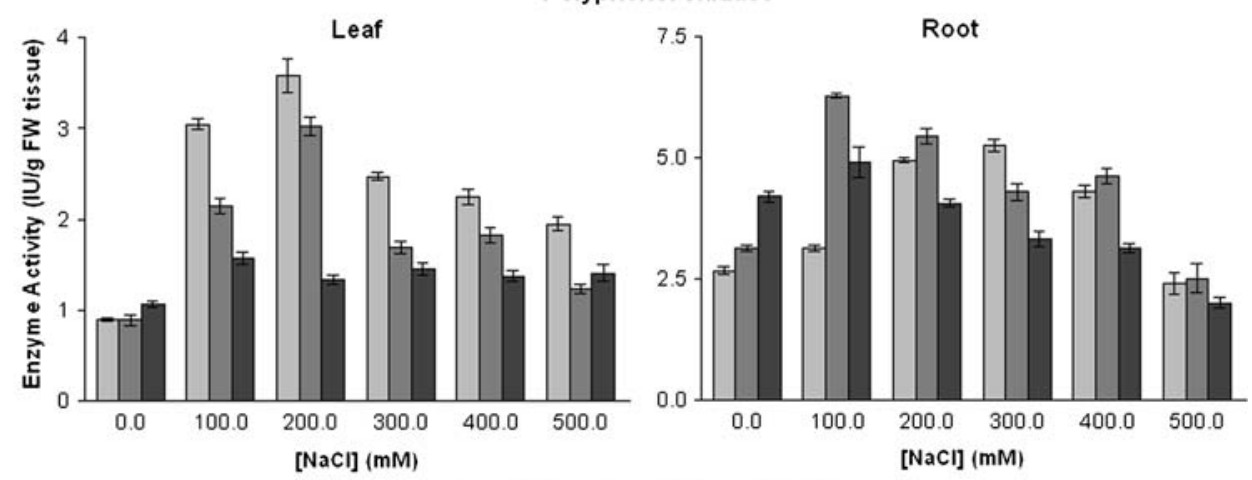


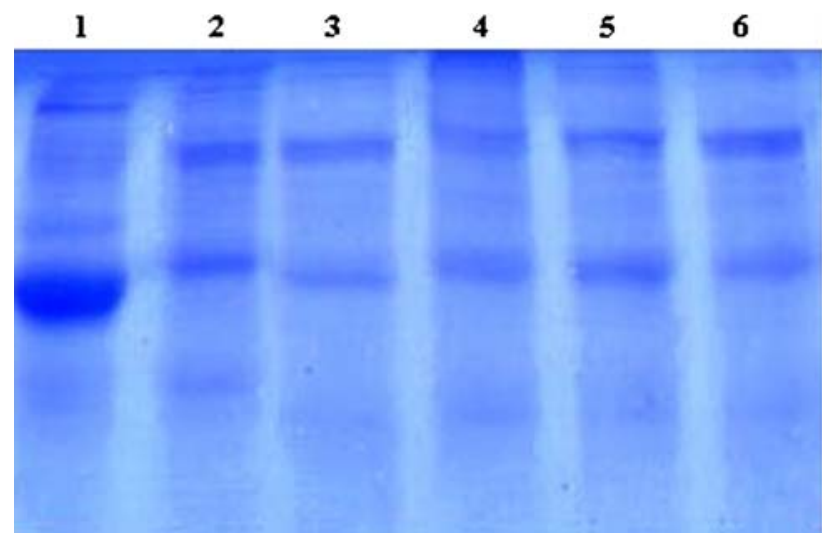

Fig. 7 SDS-PAGE pattern of salt stressed seedlings of Lablab purpureus. $100 \mu \mathrm{g}$ soluble protein extracted from control (lane 1) and stressed seedlings (lane 2-6, 100-500 mM, respectively) were resolved on a $10 \%$ gel and stained with Coomassie Brilliant Blue R250

of $\mathrm{NaCl}$ employed. Nevertheless, two bands, a very high molecular weight band and another of intermediate size decreased in their intensity under all the employed $\mathrm{NaCl}$ concentration. Another high molecular weight band exhibited intensification under salt stress (Fig. 7).

\section{Discussion}

Agronomic characteristics, such as survival, yield, growth rate, RWC, and biomass are common criteria for measuring salt tolerance. However, biochemical and physiological parameters such as antioxidants, antioxidant enzymes and metabolite- mediated enzymes, osmolytes, lipid peroxidation, and chlorophyll destruction offer highly relevant criteria to evaluate the extent of tolerance.

Salinity stress affects the development and underlying mechanisms such as seed germination, seedling growth and vigor, vegetative growth, flowering, and fruit set. A general decline in physical parameters in Lablab during salt stress in time- and concentration-dependent manner indicated that the salt stress above $100 \mathrm{mM}$ significantly affects the growth potential. The decrease in growth can be attributed to the reduced cell elongation resulting from decreased turgor, cell volume, and cell growth, as has been observed by Boyer (1988). Contrary to salinity-stressed soybean (Murat et al. 2008) and chickpea (Welfare et al. 2002), Lablab seedlings showed a moderate reduction in fresh and dry weights up to $300 \mathrm{mM}$. Observed changes in shoot and root lengths of Lablab were similar to those of salt-tolerant Lucerne (Rogers et al. 2003), and salt- and temperaturestressed French bean (Nagesh and Devaraj 2008). Nevertheless, salinity influenced Lablab shoot growth more negatively than root, similar to Medicago citrina (Sibole et al. 2005), indicating the moderate tolerance of the plant. Reduced effect on the root growth could be due to expenditure of more photosynthetic energy on root growth in search of water and/or reducing water loss, thus maintaining higher water relations.

Stress-induced decrease in mean area and number of leaves of Lablab seedlings also contributed for the reduced fresh mass and growth rate. A similar observation has been made in a few trees (Gurumurthy et al. 2007). Such alterations have been correlated with increased $\mathrm{ABA}$ and decreased IAA in the salt-stressed plants. The RWC values of root, leaves, and shoot of Lablab also suggested such an arrangement.

The production of ROS has been shown to be a consequence of photooxidative processes occurring during abiotic stress conditions such as; chilling, drought, salt, and ozone stress (Foyer and Mullineaux 1994). During abiotic stress, PSII becomes progressively reduced and ultimately produces $\mathrm{H}_{2} \mathrm{O}_{2}$. ROS generation occurs via electron transport reactions in mitochondria and chloroplasts. The Mehler reaction in chloroplasts generates superoxide that is converted to $\mathrm{H}_{2} \mathrm{O}_{2}$. The progressive increase in the levels of $\mathrm{H}_{2} \mathrm{O}_{2}$ in leaves and roots with increasing concentration of salt indicated the prevalence of greater stress in Lablab up to $48 \mathrm{~h}$ of exposure. The Lablab plant does not seem to be tolerant to salt beyond $300 \mathrm{mM}$ and $48 \mathrm{~h}$ of exposure. The elevated levels of $\mathrm{H}_{2} \mathrm{O}_{2}$ in stressed leaves could be due to an increase in activity of SOD (Brou et al. 2007) and a decrease in activity of CAT (Willekens et al. 1997). Our results are in conformity with chill-stressed cucumber (Lee and Lee 2000) and acid rain-treated French bean (Velikova et al. 2000). Apart from removing acyl peroxides derived from lipid peroxidation, and reduction of disulphide bonds formed by ROS action on proteins, the GSH also acts as a reductant for regeneration of ASC from dehydroascorbic acid. Parallel increase in $\mathrm{H}_{2} \mathrm{O}_{2}$ and GSH in Lablab is also in accordance with the observed induction of GSH synthesis by $\mathrm{H}_{2} \mathrm{O}_{2}$ (May and Leaver 1993).

The strength of the oxidative stress relies on the interaction of several factors that determine the antioxidant status of the plant. Ascorbate, the key antioxidant for the elimination of ROS in the leaves and roots of stressed seedlings increased progressively with exposure time and concentration (Table 3), indicating effective scavenging of ROS in Lablab. As powerful reducing agent, ASC maintains chloroplastic $\alpha$-tocopherol and metalloenzyme activity and acts as reductant in enzymatic reactions and free radical scavenging of superoxide and $\mathrm{H}_{2} \mathrm{O}_{2}$ radicals nonenzymatically. ASC appears to have significant role in Lablab. The increase of GSH in both leaf and root tissues is considered to be responsible for generating ascorbate via the ascorbate-GSH cycle. Parallel increase in ascorbate and GSH at extended exposure and very high concentration of 
salt in Lablab suggests efficient working of ascorbateglutathione cycle.

Phenols protect the cells from potential oxidative damage and increase stability of cell membrane (Burguieres et al. 2006). Antioxidative properties of phenols arise from their high reactivity as hydrogen and electron donors, the ability of polyphenol-derived free radical to stabilize the unpaired electron (chain breaking function), and their ability to chelate transition metal ions thereby terminating the Fenton reaction (Rice-Evans et al. 1997). They can also alter peroxidation kinetics by reducing the fluidity of the membrane and preventing the diffusion of free radicals (Arora et al. 2000). A marginal enhancement of total phenols in leaves under higher concentration of $\mathrm{NaCl}$ suggested that signals for these secondary metabolitemediated response is elicited under extreme dehydration stress in Hyacinth bean. Levels of total phenol in roots, however, showed a decline with time and concentration of $\mathrm{NaCl}$, suggesting no remarkable role in roots.

The accumulation of proline in the cytosol of certain species has been shown to contribute to osmotic adjustments and suggested to play a role as stress-related signal molecule (Hare and Cress 1997). Parre et al. (2007) have demonstrated that phospholipase-C mediates the accumulation of proline in response to osmotic effect of $\mathrm{NaCl}$. Gradual increase in proline in leaves of hyacinth bean reflected the fact that increasing concentration of $\mathrm{NaCl}$ has caused considerable osmotic effect, and the plant employs proline as an osmoprotectant. Such responses have been observed in variety of leguminous plants, including pea (Bandeoglu et al. 2004) and chickpea (Eyidogan and $\mathrm{Oz}$ 2007) under salt stress. Proline biosynthesis and accumulation bears a direct correlation with carbohydrate levels and is related to acquisition of salt tolerance in plants (Hare and Cress 1997). In addition to their role in osmoprotection, soluble sugars play an important role in biosynthetic processes, energy production, stabilization of cellular membranes, maintenance of turgor, and signaling (Nayer and Reza 2008). Elevated levels of soluble sugars in concentration-dependent manner during the first $24 \mathrm{~h}$ of exposure suggested probability of sugarmediated proline biosynthesis in Lablab purpureus. However, inverse relationship between proline and soluble sugars during prolonged exposure indicated no significant role for carbohydrates and/or carbohydrate metabolic enzymes in osmotic regulation.

ROS causes chlorophyll degradation and membrane lipid peroxidation. Decrease in chlorophyll and carotenoid contents of leaves in response to salt stress is a general phenomenon (Parida and Das 2005). However, there are exceptions showing increased pigment content (Wang and Nil 2000). Decreased chlorophyll content in Lablab purpureus indicated susceptibility to prolonged exposure and high salt concentration. Such decrease in chlorophyll contents have been reported from salt-sensitive cotton (Meloni et al. 2003) and Phaseolus vulgaris (Yasar 2007). In addition to oxidative damage, increased chlorophylase activity has been implicated in chlorophyll degradation during stress conditions (Singh and Jain 1981). Thus, the observed reduction in chlorophyll content could be a result of both decreased synthesis and increased degradation under salt stress.

The increase in sugar concentration may be a result of starch degradation, inhibition of starch synthesis (Chaves 1991), sequestration of photosynthates, and inhibition of invertase. A marginal increase in total sugar during first $24 \mathrm{~h}$, a decline during further exposures in leaves, and a measurable increase during all the time points of exposure up to $0.3 \mathrm{M} \mathrm{NaCl}$ in roots of Lablab indicated that osmotic homeostasis differs in leaves and roots. The decreased activity of invertase in both leaves and roots of Lablab also supports these results. The results also indicated that sugarmediated osmotic regulation in leaves holds good only for short-term exposures.

The accumulation of free radicals in stressed plants cause oxidation of polyunsaturated fatty acids in the plasma membrane resulting in the formation of malondialdehyde or TBARS (Hernandez et al. 2000). Elevated levels of TBARS are thus a measure of lipid peroxidation and membrane damage. Correlation of TBARS with concentration and duration of salinity suggested a greater lipid peroxidation in roots. Such increase in root TBARS content was observed in number of plants, viz. O. sativa (Khan and Panda 2008) and C. angustifolia (Agarwal and Pandey 2004). Absence of significant increment in peroxidation in Lablab bean beyond $300 \mathrm{mM} \mathrm{NaCl}$ could be a result of inhibition of peroxidation by ROS at higher concentrations of $\mathrm{NaCl}$. This inhibition is due to decrease in water potential from the very beginning of stress, which might limit diffusion of $\mathrm{H}_{2} \mathrm{O}_{2}$ from its sight of generation. Similar observation has been reported for tomato roots (Gapinska et al. 2008).

Antioxidant enzymes, which play crucial role in mitigation of oxidative stress, have been shown to be elevated under variety of stresses (Manchanda and Garg 2008). APX and POX which reached highest levels beyond $200 \mathrm{mM}$ $\mathrm{NaCl}$ at 48 and $72 \mathrm{~h}$ of exposure coincided with increased levels of $\mathrm{H}_{2} \mathrm{O}_{2}$, indicating their role in detoxification of $\mathrm{H}_{2} \mathrm{O}_{2}$ in Lablab leaves under high salinity stress. Higher levels of GSH, GR and ascorbic acid, which coincided with enhanced levels of POX, further suggested that GR activity provided the reductant (reduced ASC), necessary for POX to reduce $\mathrm{H}_{2} \mathrm{O}_{2}$ under salinity stress of up to $400 \mathrm{mM}$. A similar trend in POX and GR has been reported from chickpea stressed with $\mathrm{NaCl}$ (Eyidogan and $\mathrm{Oz}$ 2007). Only a marginal increase in POX up to $200 \mathrm{mM}$ and steady decline in GR indicated that the combination of the two 
enzymes do not contribute to reduction of $\mathrm{H}_{2} \mathrm{O}_{2}$ in roots, which is 7-8 times higher than leaf. This apart, the isozyme patterns of the POX and GR in roots and leaves differed, indicating a different set of genes being involved in roots and leaves of Lablab. Increased GR is associated with salt tolerance; however, the reduced levels of GR in roots of Lablab suggested that the root is not tolerant, especially beyond $200 \mathrm{mM}$. From these observations, it can be opined that the Lablab root system does not utilize GSH-ASC cycle efficiently similar to chickpeas and French bean (Nagesh Babu and Devaraj 2008).

Along with POX and GR, CAT is also involved in detoxification of $\mathrm{H}_{2} \mathrm{O}_{2}$. A slight drop in root and a steep decline in leaf CAT activity in Lablab suggested no role for CAT in leaves. Nevertheless, levels of CAT and isozyme pattern in roots indicated a probable role for the enzyme in detoxification of ROS. This kind of increased POX and GR associated with decreasing CAT in leaves has been reported from chickpea (Eyidogan and Oz 2007) and French bean (Nagesh Babu and Devaraj 2008). Contrary to this, elevated levels of POX in roots and enhanced levels of GR, POX, and CAT observed in lentils suggested better protection of root system against salt.

PPO activity increases during the progression of stress and is a possible tolerance mechanism as demonstrated in peach seedlings subjected to freezing stress (Szalay et al. 2005) and salt-stressed C. angustifolia (Agarwal and Pandey 2004). PPO levels in Lablab indicated a possible role during early $24 \mathrm{~h}$ of exposure at lower concentration of salt up to $300 \mathrm{mM}$, in both, leaf, and root tissues.

Apart from antioxidant enzymes, which have been unequivocally implicated in stress response, there are also scanty reports of induction of metabolite enzyme, $\beta$ amylase under abiotic stress (Yang et al. 2007). Increased levels of amylase, as observed by in vitro levels and in-gel assays suggested induction of amylase in leaves of Lablab. The induction of amylase could be due to $\mathrm{NaCl}$-induced osmotic signals, which in turn could be linked to increased maltose content or total soluble sugars. Phosphatases are known to act under salt and water stress by maintaining a certain level of inorganic phosphate, which can be cotransported with $\mathrm{H}^{+}$along a gradient of proton motive force (Olmos and Hellin 1997). Lohrasebi et al. (2007) and others have identified APs which are specifically expressed under stress and phosphate starvation. The isozyme patterns in root and leaves of Lablab indicated a similar expression pattern. The decline of AP in leaf tissue suggested that the salt stress represses these genes while inducing those specific to root.

In conclusion, Lablab plant is tolerant to salt up to $200 \mathrm{mM}$, which is well above the general levels for legumes. The antioxidant system in leaves involves the non-enzymatic components GSH, Asc and proline, and enzymatic components such as POX, GR and to a lesser extent, PPO. The plant exhibited distinct salt-response mechanisms in leaves and roots, and the root system is less tolerant than the leaf system.

Acknowledgment Myrene R D'souza acknowledges the Council for Scientific and Industrial Research (CSIR), New Delhi, India, for JRF (Award No. 09/039(0080)/2007-EMR-I).

\section{References}

Aebi H (1984) Catalase in vitro. Methods Enzymol 105:121-126

Agarwal S, Pandey V (2004) Antioxidant enzyme responses to $\mathrm{NaCl}$ stress in Cassia angustifolia. Biol Plant 48(4):555-560

Agarwal S, Shaheen R (2007) Stimulation of antioxidant system and lipid peroxidation by abiotic stresses in leaves of Momordica charantia. Braz J Plant Physiol 19(2):149-161

Allen MM (1968) Simple conditions for growth of unicellular bluegreen algae on plates. J Phycol 4:1-4

Arnon DL (1949) Copper enzymes in isolated chloroplasts. Polyphenol oxidase in Beta vulgaris. Plant Physiol 24:1-15

Arora A, Byrem TM, Nair MG, Strasburg GM (2000) Modulation of liposomal membrane fluidity by flavonoids and isoflavonoids. Arch Biochem Biophys 323:102-109

Bandeoglu E, Eyidogan F, Yucel M, Oktem HA (2004) Antioxidant responses of shoots and roots of lentil to $\mathrm{NaCl}$-salinity stress. Plant Growth Regul 42:69-77

Bates LS, Waldren RP, Teare ID (1973) Rapid determination of free proline for water stress studies. Plant Soil 39:205-207

Bernfeld P (1955) Amylase $\alpha$ and $\beta$. Methods Enzymol 1:149-151

Beutler E, Duron O, Kelly BM (1963) Improved method for determination of blood glutathione. J Lab Clin Med 61:882

Boyer JS (1988) Cell enlargement and growth-induced water potentials. Physiol Plant 73:311-316

Brou YC, Adolphe Z, Omar D, Murielle E (2007) Water stress induces overexpression of SOD that contribute to the production of cowpea plants against oxidative stress. Afr J Biotechnol 6(17):1982-1986

Burguieres EP, McCXue Y, Kwon In, Shelty K (2006) Effect of vitamin $\mathrm{c}$ and folic acid on seed vigour response and phenoliclinked antioxidant activity. Bioresour Technol 95:1393-1404

Carlberg I, Mannervik B (1985) Glutathione reductase. Methods Enzymol 113:488-495

Chance B, Maehly AC (1955) Assays of catalases and peroxidases. In: Methods in enzymology, vol II. Academic Press, New York, pp 764-775

Chaves MM (1991) Effects of water deficits on carbon assimilation. J Exp Bot 42(1):1-16

Chinnusamy V, Jagendorf A, Zhu JK (2005) Understanding and improving salt tolerance in plants. Crop Sci 45:37-448

Davis BJ (1964) Disc gel electrophoresis. II. Method and application to human serum proteins. Ann N Y Acad Sci 121:404-427

Eyidogan F, Oz MT (2007) Effect of salinity on antioxidant responses of chickpea seedlings. Acta Physiol Plant 29:485-493

FAO (2005) Global network on integrated soil management for sustainable use of salt-affected soils. FAO land and plant nutrition management service, Rome

Foyer CH, Mullineaux PM (1994) Causes of photooxidative stress and amelioration of defense systems in plants. CRC Press, Boca Raton, FL

Gapinska M, Sklodowska M, Gabara B (2008) Effect of short- and long-term salinity on the activities of antioxidative enzymes and lipid peroxidation in tomato roots. Acta Physiol Plant 30(1):11-18 
Gurumurthy BR et al (2007) Influence of soil salinity on relative biomass and critical limits of growth in selected tree species. Karnataka J Agric Sci 20(1):133-134

Hare PD, Cress WA (1997) Metabolic implications of stress-induced proline accumulation in plants. Plant Growth Regul 21:79-102

Heath RL, Packer L (1968) Photoperoxidation in isolated chloroplasts. Kinetics and stoichiometry of fatty acid peroxidation. Arch Biochem Biophys 125:189-198

Hernandez JA, Jimenez A, Mullineaux P, Sevilla F (2000) Tolerance of pea (Pisum sativum L.) to a long term salt stress is associated with induction of antioxidant defences. Plant Cell Environ 23:853-862

Hoerling N, Svensmark O (1976) Carboxyl esterase with different substrate specificity in human brain extracts. J Neurochem 27:523-528

Kanade SR, Paul B, Rao AGA, Gowda LR (2006) The conformational state of polyphenol oxidase from field bean (Dolichos lablab) upon SDS and acid-pH activation. Biochem J 395:551-562

Khan MH, Panda SK (2008) Alterations in root lipid peroxidation and antioxidative responses in two rice cultivars under $\mathrm{NaCl}$-salinity stress. Acta Physiol Plant 30(1):81-89

Kolodyazhnaya YS, Kutsokon NK, Levenko BA, Syutikova OS, Rakhmetov DB, Kochetov AV (2009) Transgenic plants tolerant to abiotic stresses. Cytol Genet 43(2):132-149

Laemmli UK (1970) Cleavage of structural proteins during the assembly of the head of $T_{4}$ bacteriophage. Nature 227:680-685

Lee DH, Lee CB (2000) Chilling stress-induced changes of antioxidant enzymes in the leaves of cucumber: in gel enzyme activity assays. Plant Sci 159:75-85

Lohrasebi T, Malboobi MA, Samaeian A, Sanei V (2007) Differential expression of Arabidopsis thaliana acid phosphatases in response to abiotic stresses. Iran J Biotechnol 5(3):130-139

Lowry OH, Rosebrough NJ, Farr AR, Randoll RJ (1951) Protein measurement with Folin-Phenol reagent. J Biol Chem 193:265-275

Maass BL, Jamnadass RH, Hanson J, Pengelly BC (2005) Determining sources of diversity in cultivated and wild Lablab purpureus related to provenance of germplasm by using amplified fragment length polymorphism. Genet Resour Crop Evol 52:683-695

Mackinney G (1941) Absorption of light by chlorophyll solutions. J Biol Chem 140:315-322

Manchanda G, Garg N (2008) Salinity and its effects on functional biology of legumes. Acta Physiol Plant 30:595-618

May MJ, Leaver CJ (1993) Oxidative stimulation of glutathione synthesis in Arabidopsis thaliana suspension cultures. Plant Physiol 103:621-627

Meloni DA, Oliva MA, Martinez CA, Cambraia J (2003) Photosynthesis and activity of superoxide dismutase, peroxidase and gutathione reductase in cotton under salt stress. Environ Exp Bot 49:69-79

Miller GL (1959) Use of dinitrosalicylic acid reagent for the determination of sugar. Anal Chem 31:426

Mittova V, Guy M, Tal M, Volokita M (2004) Salinity up-regulates the antioxidative system in root mitochondria and peroxisomes of the wild salt-tolerant tomato species Lycopersicon pennellii. J Exp Bot 55(399):1105-1113

Munns R (2002) Comparative physiology of salt and water stress. Plant Cell Environ 25:239-250

Murat T, Ruveyde T, Fikret (2008) Changes in micronutrients, dry weight and plant growth of soybean (Glycine max L. Merrill) cultivars under salt stress. Afr J Biotechnol 7(11):1650-1654

Nagesh Babu R, Devaraj VR (2008) High temperature and salt stress response in French bean (Phaseolus vulgaris). Aust J Crop Sci 2(2):40-48

Nayer M, Reza H (2008) Drought induced accumulation of soluble sugars and proline in two maize varieties. World Appl Sci J 3(3):448-453
Olmos E, Hellin E (1997) Cytochemical localization of ATPase plasma membrane and acid phosphatase by cerium based in a salt-adapted cell line of Pisum sativum. J Exp Bot 48:1529-1535

Parida AK, Das AB (2005) Salt tolerance and salinity effects on plants: a review. Ecotoxicol Environ Saf 60:324-349

Parre E et al (2007) Calcium signaling via phospholipase $\mathrm{C}$ is essential for proline accumulation upon ionic but not ionic hyperosmotic stresses in Arabidopsis. Plant Physiol 144:503512

Rice-Evans CA, Miller NJ, Paganga G (1997) Antioxidant properties of phenolic compounds. Trends Plant science 2:152-159

Roe JH (1955) The determination of sugar in blood and spinal fluid with anthrone reagent. J Biol Chem 212:335-343

Rogers ME, Grieve CM, Shannon MC (2003) Plant growth and ion relations in lucerne (Medicago sativa L.) in response to the combined effects of $\mathrm{NaCl}$ and P. Plant Soil 253(1):187-194

Sadasivam S, Manickam A (1997) Vitamins. In: Sadasivam S, Manickam A (eds) Biochemical methods, 2nd edn. New Age International (P) Limited, New Delhi, pp 185-186

Sibole JV, Cabot C, Michalke W, Poschenrieder C, Barcelo J (2005) Relationship between expression of the PM H + -ATPase, growth and ion partitioning in the leaves of salt-treated Medicago species. Planta 221(4):557-566

Singh G, Jain S (1981) Effect of some growth regulators on certain biochemical parameters during seed development in chickpea under salinity. Indian J Plant Physiol 20:167-179

Slinkard K, Singleton VL (1977) Total phenol analysis: automation and comparison with manual methods. Am J Enol Vitic 28:4955

Sridhar R, Ou SH (1972) Extracellular enzymes produced by Pyricularia oryzae. Philipine Phytopath 8:52-56

Szalay L, Hegedus A, Stefanovitis-Banyai E (2005) Presumable protective role of peroxidase and polyphenol oxidase enzymes against freezing stress in peach (Prunus persica/L./Batsch) Acta. Biologica Sze 49(1-2):121-122

Turner NC, Kramer PJ (eds) (1980) Adaptation of plant to water and high temperature stress. Wiley, New York, pp 207-230

Velikova V, Yordanov I, Edreva A (2000) Oxidative stress and some antioxidant system in acid rain treated bean plants: protective role of exogenous polyamines. Plant Sci 151:59-66

Wang Y, Nil N (2000) Changes in chlorophyll, ribulose biphosphate carboxylase-oxygenase, glycine betaine content, photosynthesis and transpiration in Amaranthus tricolor leaves during salt stress. J Hortic Sci Biotechnol 75:623-627

Webb RP, Allen RD (1995) Isolation and characterization of a cDNA for spinach cytosolic ascorbate peroxidase. Plant Physiol 108:1325

Welfare K, Yeo AR, Flowers TJ (2002) Effect of salinity and ozone, individually and in combination on the growth and ion contents of two chickpea (Cicer arietinum L.) varieties. Environ Pollut 120(2):397-403

Willekens $\mathrm{H}$ et al (1997) Catalase is a sink for $\mathrm{H}_{2} \mathrm{O}_{2}$ and is indispensable for stress defence in $\mathrm{C}_{3}$ plants. EMBO $\mathrm{J}$ 16(16):4806-4816

Yang SH, Wang LJ, Li SH (2007) Ultraviolet-B irradiation induced freeing tolerance in relation to antioxidant system in winter wheat (Triticum aestivum L.) leaves. Environ Exp Bot 60:300-330

Yasar F (2007) Effects of salt stress on ion and lipid peroxidation content in Green beans genotypes. Asian J Chem 19:1165-1169

Zhu D, Scandalios JG (1993) Maize mitochondrial manganese superoxide dismutases are encoded by a differentially expressed multigene family. Proc Natl Acad Sci USA 90(20):9310-9314 